\title{
Reconstruction of burn contractures with free anterolateral thigh flap in various anatomic sites
}

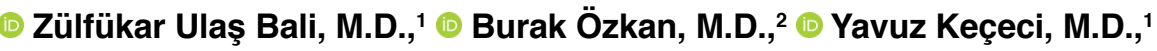 \\ (1) Nilgün Ertaş, M.D., ${ }^{2}$ ㄴ) Levent Yoleri, M.D. ${ }^{1}$ \\ ${ }^{1}$ Department of Plastic, Reconstructive and Aesthetic Surgery, Celal Bayar University Faculty of Medicine, Manisa-Turkey \\ ${ }^{2}$ Department of Plastic, Reconstructive and Aesthetic Surgery, Başkent University Faculty of Medicine, Ankara-Turkey
}

\begin{abstract}
BACKGROUND: Burn contractures that cause a restriction in extremity movements have to be reconstructed. Free microvascular flaps are generally needed in cases of severe contractures. The ideal free flap for severe contracture defects has to have a large skin island without bulk and a long pedicle for preventing recurrence and tension-free adaptation. Anterolateral thigh flap (ALT flap) that meets these features has widely been used for several indications in reconstructive surgery. Usage of ALT flap in burn contracture was described for burn and axillary contractures in literature. In this study, the usage of free ALT flaps in various anatomic contracture sites was reported.
\end{abstract}

METHODS: Fifteen free ALT flaps were performed in 14 ( 12 male, two female) patients with a mean age of 36.6 . Burn contracture defects in neck, axilla, popliteal, cubital region, plantar foot and hand were reconstructed with ALT flap.

RESULTS: No total flap loss was encountered. Distal flap necrosis was seen in one case. All patients had significant improvement in a range of motions. Recurrence in contracture was seen in one patient with hand flexor contracture due to lack of physical treatment.

CONCLUSION: ALT flap can safely be used in various anatomic contracture sites. Suprafascial elevation of the flap can be preferred for better adaptation in the neck, hand and foot and prevention of bulky appearance.

Keywords: ALT flap; burn contracture; burns.

\section{INTRODUCTION}

Reconstruction of burn contractures is one of the most performed plastic surgery operations. Regaining range of motion, prevention of re-contracture, maintaining superior aesthetic and functional results are the main goals in burn contracture reconstruction. Although the reconstruction of linear and moderate contractures is well described, microsurgical free tissue transfers are usually needed in large burn contractures without healthy adjacent skin. A flap with a large skin island and long pedicle is considered when a free flap is needed in burn reconstruction cases. Preference of the flap donor site generally depended on the defect size, depth and condition of recipient's vessels after trauma. Fascia cutaneous or free perforator flaps are preferred to bulky flaps such as muscu- locutaneous flaps, especially in joint contractures that bulk limits the range of motion. Since its description in 1984, Anterolateral thigh (ALT) free flap has become a workhorse flap in reconstructive microsurgery. ${ }^{[1]}$ Its large skin territory and thickness, pedicle length and minimal donor site morbidity are the main advantages in the microvascular transfer of ALT flap. ${ }^{[2]}$ ALT flap can be used in wide burn scar contracture defects. Limited cases or reconstruction of limited contracture sites were published in the literature. Our aim in this study is to present the feasibility of free ALT flaps in different anatomic locations in burn reconstruction.

\section{MATERIALS AND METHODS}

From 2016 to 2019 , 15 burn contractures were reconstruct-

Cite this article as: Bali ZU, Özkan B, Keçeci Y, Ertaş N, Yoleri L. Reconstruction of burn contractures with free anterolateral thigh flap in various anatomic sites. Ulus Travma Acil Cerrahi Derg 2021;27:337-343.

Address for correspondence: Burak Özkan, M.D.

Başkent Üniversitesi Tıp Fakültesi, Plastik, Rekonstrüktif ve Estetik Cerrahi Anabilim Dalı, Ankara, Turkey

Tel: +90 312 - 2121941 E-mail: burakozkan1985@hotmail.com

Ulus Travma Acil Cerrahi Derg 2021;27(3):337-343 DOI: 10.14744/tjtes.2020.89195 Submitted: 03.03.2020 Accepted: 29.04.2020

Copyright 2021 Turkish Association of Trauma and Emergency Surgery 
ed in different anatomic sites in 14 patients. There were 12 male and two female patients. The patients' ages ranged from 17 to 54. Mean follow-up was 22 months (ranging from 6 to 32 months.) Burn contractures were located in the neck in five patients, in the popliteal region in five patients, two cases in the axillary region, one patient in the hand, one patient in the cubital region, and one patient in the plantar foot. All contractures were mature burn contractures lasting from two to six years and all the patients had a history of physical treatment and compression scar therapy more than three months before their admission to our clinic. A preoperative range of emotions was recorded. All operations started with contracture release, and defects were reconstructed with an anterolateral thigh free flap. All microvascular anastomoses were performed by a single surgeon. Temporary Penrose drains were placed around the pedicle and Jackson Pradd drains were administered to the donor site. A single dose of intravenous heparin $(100 \mathrm{lU} / \mathrm{kg})$ perioperatively and low molecular weight heparin treatment twice a day for two weeks was administered to patients for clotting prevention. Patients were immobilized one-week post-operatively. All patients were referred to physical treatment after suture removal.

\section{RESULTS}

The mean operative time for ALT harvesting and in setting was four hours (3-5.5 hours). The mean flap size was $13 \times 22$ $\mathrm{cm}$. All the donor sites were closed primarily, except one patient with a $16 \times 20 \mathrm{~cm}$ flap was needed. Penrose drains were discarded on the post-operatively second day and Jackson Pradd drains were taken out after donor site discharge were lower than $20 \mathrm{cc} /$ day. Mean hospitalization time was nine days ( 8 to 22 days). All flaps were survived; distal flap necrosis was seen in one patient, which healed secondarily without intervention. No hematoma, seroma or the infec- tion was encountered. Patient's demographics, localization of contractures, preoperative/postoperative ROMs, defect/flap sizes and complications are demonstrated in Table I. Case examples of a neck contracture and popliteal contracture will be described further.

\section{Case Example for Neck Contracture}

Patient 7- An 18-year-old male patient with neck contracture was admitted to our clinic for difficulty in neck movements. The patient had a scald burn 12 years ago and has a neck extension restriction with a ROM of 60 degrees (Fig. Ia). A suprafascial free ALT flap was planned before operation for resurfacing burn contracture defect. A hand Doppler was used for detecting lateral circumflex femoral artery perforators. Perforators were marked after chasing Doppler signals. Patient was operated in supine position with neck extended. Neck scar tissue was excised down to the subplatysmal level which platysma muscle was severely injured in burn trauma. Facial artery and vein were prepared for anastomosis. After the excision and releasement of contracture, the resulting defect was measured (Fig. Ib). An $18 \times 10 \mathrm{~cm}$ long ALT flap was designed according to defect and preoperatively marked perforators. Flap was raised inferior-superior, anterior-lateral direction suprafascially to perforator zone and perforators were followed down to the vastus lateralis muscle (Fig. Ic). No muscle cuff was included to pedicle and pedicle was lengthened after chasing in intermuscular septum between vastus lateralis and rectus femoris. Donor site closed with a split-thickness skin graft. Pedicles were ligated and flap was divided after an $8 \mathrm{~cm}$ long pedicle was maintained. Pedicles were washed with a heparinized solution before inset. After placing immobilization, sutures anastomoses were performed to the facial artery to a vein without tension and kinging with 8.0 Dylon sutures. Penrose drains were placed under ALT
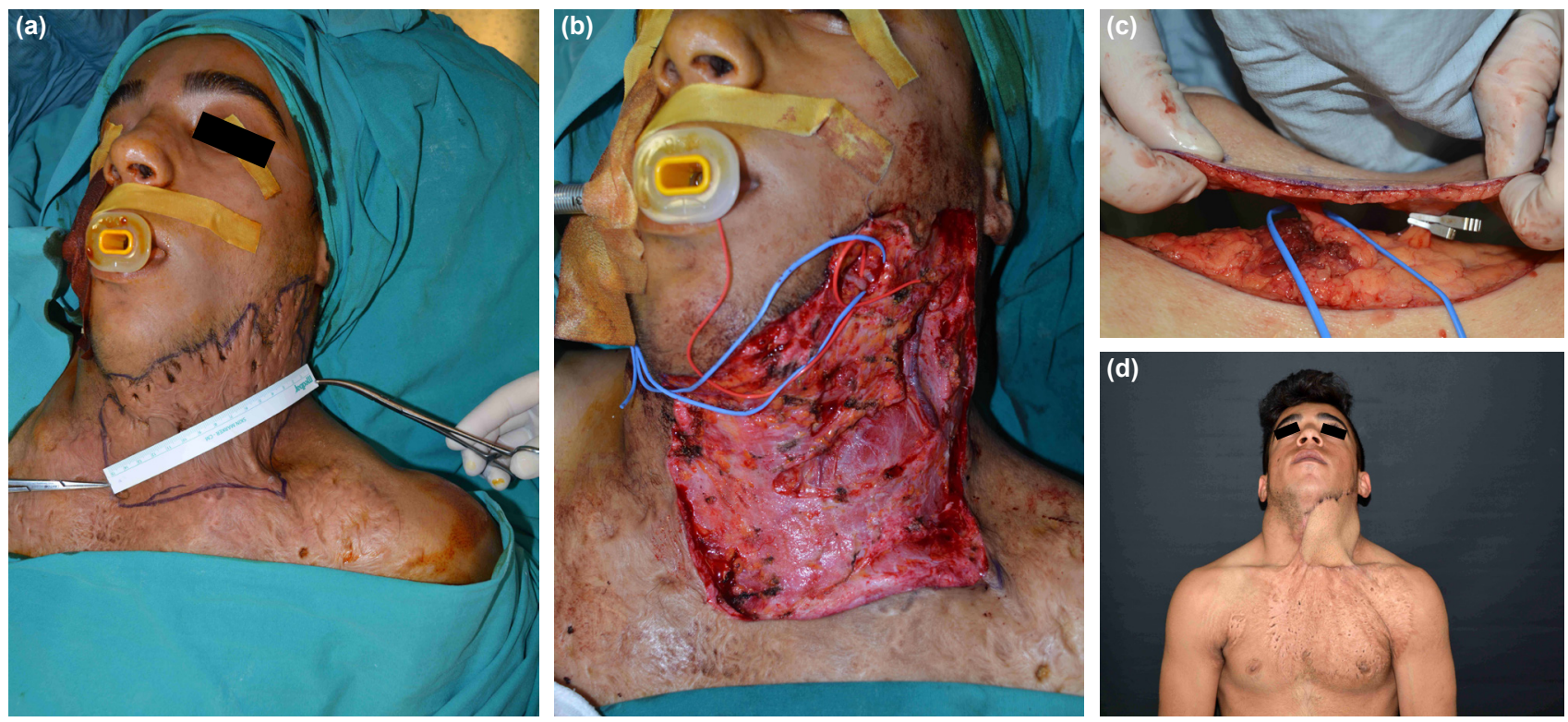

Figure 1. (a) Intraoperative view of the neck contracture before excision. (b) The defect after burn scar excision. (c) View of suprafascial ALT flap. (d) Post-operative $7^{\text {th }}$-month view of the patient. 


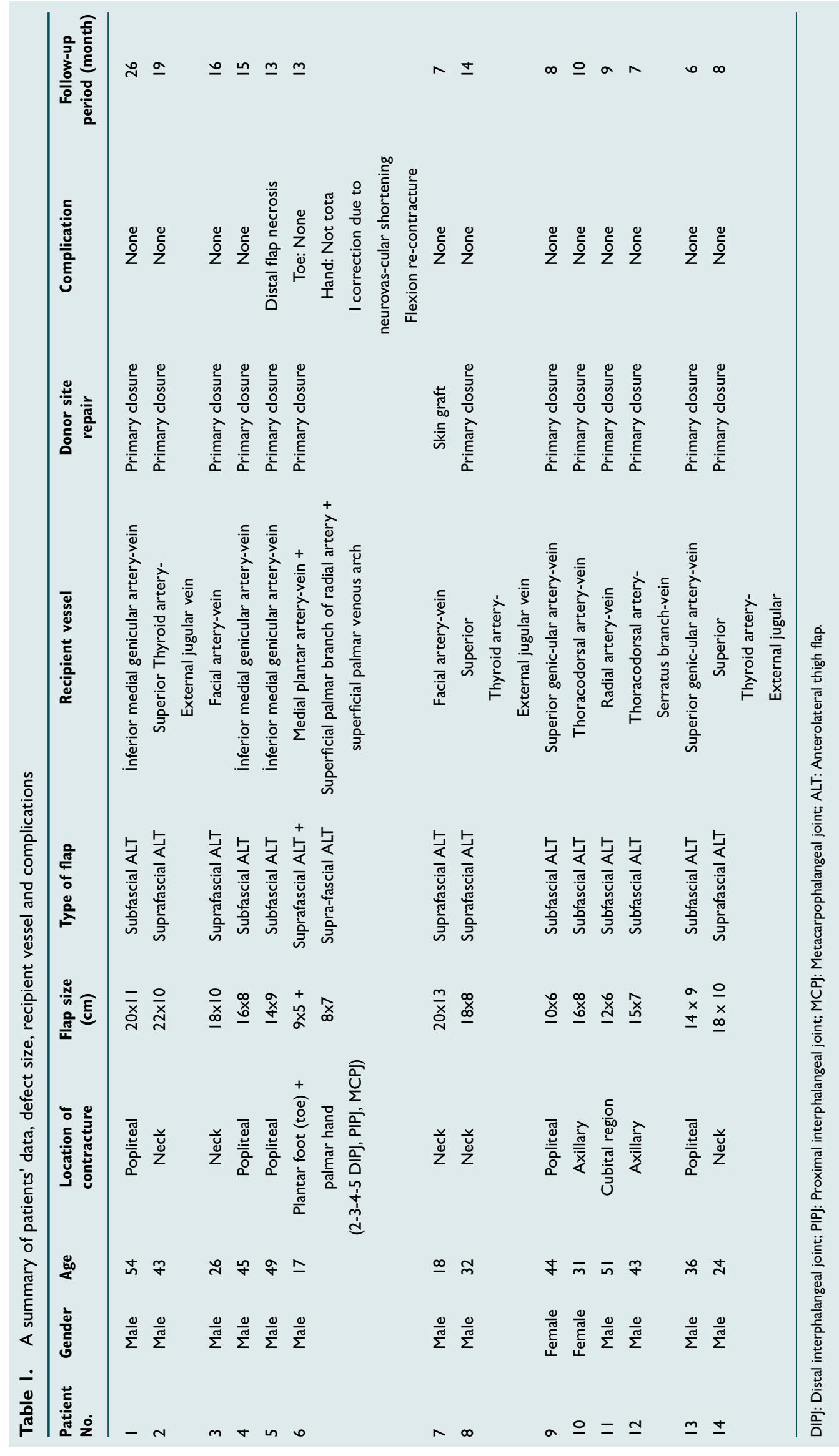


flap; donor site closed with a split-thickness skin graft. No complications were encountered postoperatively. Post-operative 7-month result of the patient is demonstrated in Figure Id.

\section{Case Example for Popliteal Contracture}

Patient 4- A 45-year-old male patient with 30 years history of scald burn in his left popliteal region was admitted to our clinic. The patient had a severe restriction in leg extension (Fig. 2a). A microvascular ALT flap was planned for closing post release defect. Perforators were marked with hand Doppler. Patient was operated in a lateral decubitus position. Scar was excised down to superior fascia. Inferior medial genicular artery and vein were prepared for end-to-end anastomosis. No additional intervention was needed to the knee joint for maintaining maximum extension. A $16 \times 8 \mathrm{~cm}$ long ALT flap was designed from the contralateral extremity. Flaps were raised inferior-superior direction superficially to perforator zone and perforators were followed down to vastus lateralis muscle (Fig. 2b). Pedicle was ligated after maintaining a $10 \mathrm{~cm}$ long pedicle. A heparinized solution was administered after division. Patients' positions were changed to prone before flap adaptation. After flap inset, microvascular anastomoses were performed in end-to-end fashion. Penrose and nega-
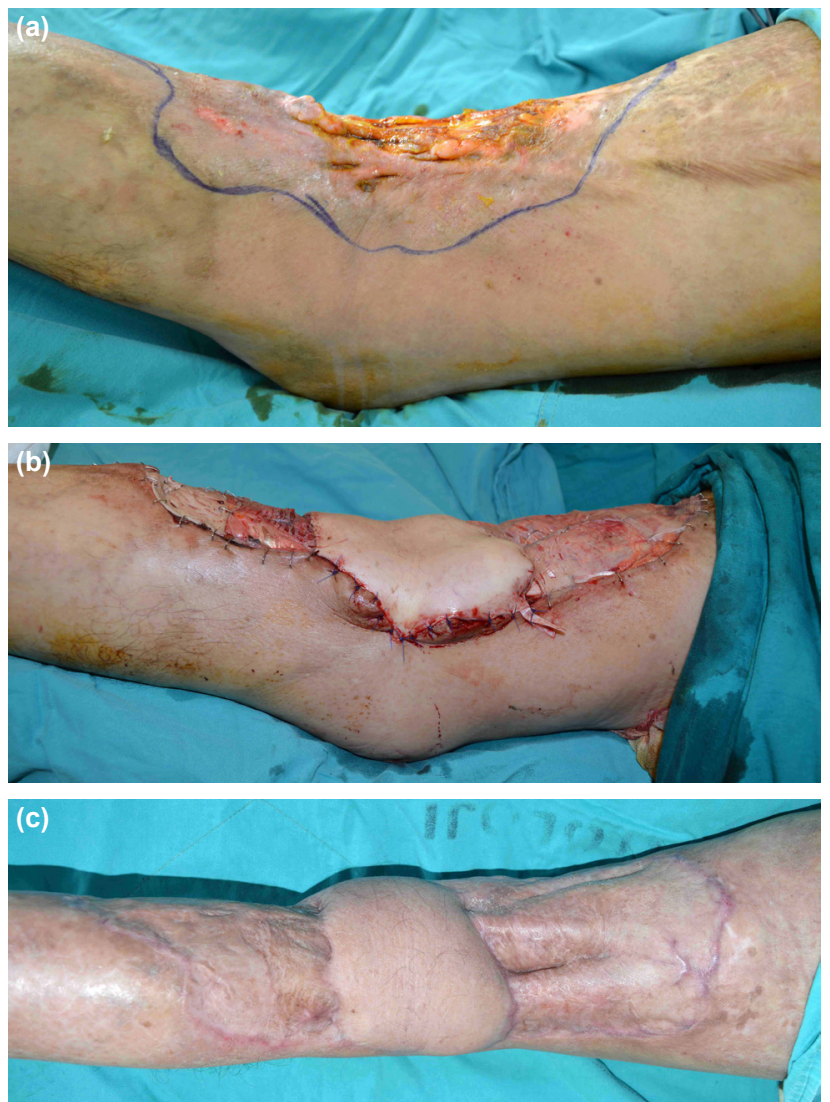

Figure 2. (a) Pre-operative view of the burn contracture of the popliteal region. (b) Post-operative view of the released contracture with ALT flap and skin grafts. (c) Post-operative $15^{\text {th }}$-month view of the patient with popliteal contracture. tive pressure drains were placed, donor site closed primarily. Patient was followed in prone position post-operative I week. No complications were encountered postoperatively. Post-operative 15-month results of the patient were demonstrated in (Fig. 2c).

\section{Case Example for Plantar Foot Contracture}

Patient 6- A 17-year-old male with burn contracture in his left toe to the plantar foot and his hand due to tandir burn that happened five years ago admitted to our clinic (Fig. 3a). Bilateral ALT flaps were planned for hand and plantar foot flexion contracture. A 9x5 sized suprafascially elevated ALT flap was elevated and anastomosed to the medial plantar artery and vein for post-burn contracture release defect (Fig. 3b, c). Donor site of ALT flap was closed primarily. No complications and re-contracture development were seen in post-operative 12 months follow-up.

\section{DISCUSSION}

Burn contractures are the leading cause of post-burn complications needed surgical intervention. Contractures that limits patient's mobilization causes discomfort and detoriated aesthetic appearance should be corrected. Contracture release algorithm may vary beyond centers, but linear and longitu-
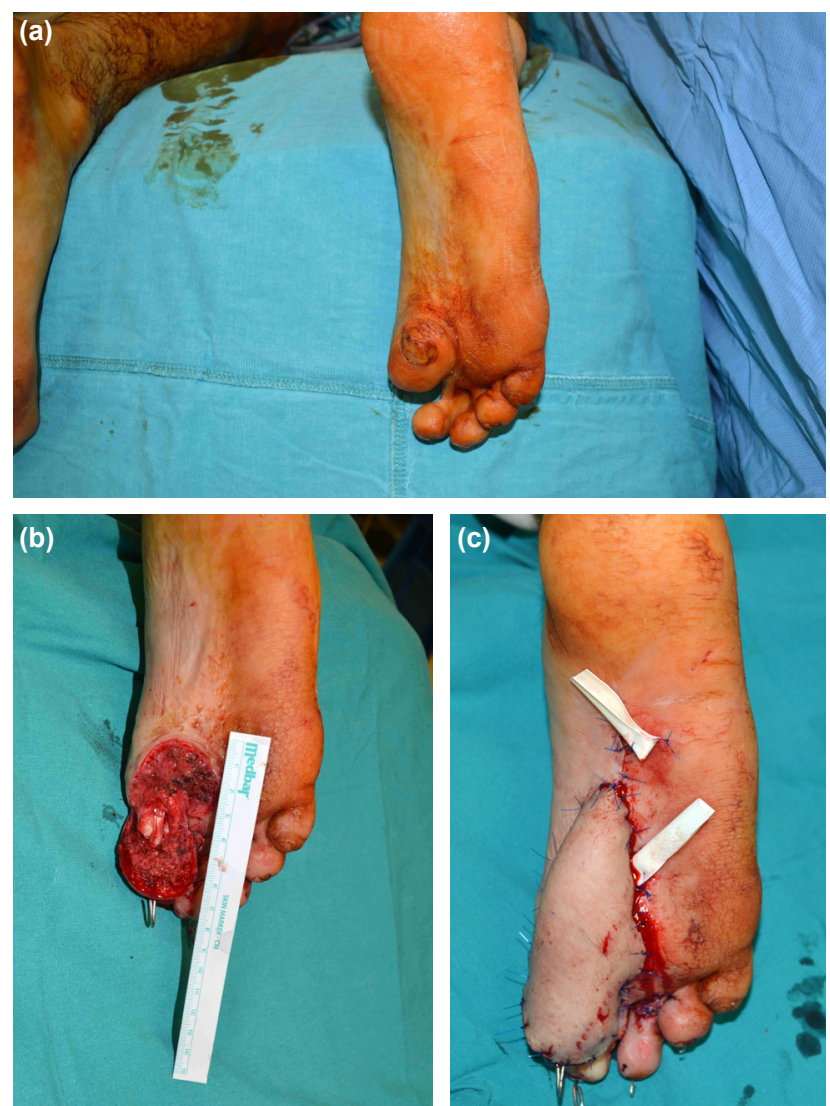

Figure 3. (a) Pre-operative view of burn contracture of the toe and plantar foot. (b) The view of the defect after contracture release. (c) Post-operative view of the Suprafascial ALT flap in the plantar foot. 
dinal bands are corrected with Z-plasty, which is a widely accepted technique. ${ }^{[3-6]}$ Transposition flap modifications, such as double opposing Z- plasty, rectangular plasty or subcutaneous pedicled local flaps, are used in broader contractures. [7,8] Reconstruction can be performed with tissue expansion or perforator included longer skin flaps, but the condition of the adjacent skin is the main limitation in burn patients. [9-11] The ideal flap for joint contractures should be in similar thickness and slightly oversized on the longitudinal axis. Free tissue transfer provides these criteria.

Microsurgical free tissue transfers are needed in cases of wide and mature contractures that the defect after contracture release cannot be closed with local tissue arrangements. Skin graft transfer can be an option in large defects, but a high possibility of contracture development, exposition of neurovascular and tendinous structures diminishes the usage of grafts. ${ }^{[12-14]}$ Free microvascular flap transfer provides the desired well-vascularized healthy tissue. There are many series of free flap reconstruction in burn contracture in the literature. ${ }^{[15]}$ Anatomic location of the contracture, defect, size the degree and depth of the burn injury, the quality of the adjacent skin, uninjured sites of the body, patients' general health status and comorbidities are the main factors affecting the free flap choice. Replacing the skin with a similar thickness is another important factor. Conventional musculocutaneous flaps like latissimus dorsi flap carry a large skin island, but the bulk remains a problem. Although pre-expansion of the flap was reported as an alternative solution, generally, a second debulking procedure is needed. ${ }^{[16,17]}$ Because of these handicaps, free perforator flaps have become a more popular and preferred method in the reconstructive era. Free perforator flaps are superior to conventional fascicutaneous and musculocutaneous flaps with their minimal donor site morbidity and thin pliable skin thickness. ALT flap has become a mostly performed perforator-free flap in many centers and has been successfully used in many reconstructive scenarios, especially in head and neck and trunk reconstruction. ${ }^{[18]}$ We preferred the ALT flap in our series due to the following reasons. I. Wide defects with neurovascular or tendinous structures exposition 2. Lack of unscarred tissue adjacent to defect 3. Previously failed operations with contracture development 4. The need for a longitudinal elliptic-shaped flap that necessitates a semicircular covering movement without bulk, which can restore contour in the joints. 5. Regaining range of motion without the need for a secondary procedure. 6 . Appropriate diameter of pedicle for anastomosis.

We performed ALT flap in five different anatomic locations. We did not encounter any problems with pedicle length and size. The ALT flap has an approximately $8-10 \mathrm{~cm}$ pedicle around $2 \mathrm{~mm}$ diameter which can be a satisfactory length for anastomosing beyond the trauma zone. ${ }^{[19]}$ Two of our cases had electric burn history and we were able to anastomose pedicle more proximal for preventing electric burns related vascular problems. Superior thyroid artery, inferior thyroid artery, facial artery and external jugular vein were used as recipient vessels in the head and neck area. We used radial artery in end to side fashion artery in the cubital region and radial ulnar arteries in wrist and hand. Inferior genicular artery was used as recipient artery in the popliteal region. We preferred end to side arterial anastomosis in the extremities and end-to-end in neck cases. In axillary contractures, our traditional method is to cover the defect with latissimus dorsi perforator flap but in our case, patient had severe disfigurement due to the burn injury in his anterolateral thorax thus we used thoracodorsal artery for anastomosis.

ALT flap harvesting has advantages for both donor and recipient sites. Advantages for donor site are I. The chance for protecting vastus lateralis when skin only flap is needed. 2 . Not to harm an important vascular network such as axial free flaps radial forearm flap. T. Harvesting the lateral femoral circumflex artery network does not deteriorate the extremity circulation apart from the rectus and vastus lateralis muscles. 3. Primary closure of the flap site. It is reported that up to 8 cm defect can be closed primarily. ${ }^{[20]}$ In our series, we all are able to close donor sites without grafting. We strongly advocate grafting should be considered when excessive tension is seen to avoid iatrogenic compartment syndrome. Two simultaneous team approaches are counted as an advantage of flap harvest, but in burn contracture cases we do not recommend harvesting flap before the eventual defect size is certain. ${ }^{[21]}$ When a larger skin island is needed, pre-expansion is an alternative. Successfully pre-expanded ALT-free flap cases were reported in the literature for covering defects after contracture release in hand and neck. ${ }^{[22,23]}$ Expansion period and two-stage operations are the main disadvantages. Advantages for the recipient site are I. Good pedicle length and diameter which helps the surgeon find a suitable recipient artery and vein in the defect area, which limits the need for further dissection 2 Skin island permits semicircular covering of the joints, so the desired contour can be achieved. 3. A healthy well-vascularized tissue without tension prevents contracture relapses. In our series, we did not encounter any contracture development after surgery.

The disadvantages of ALT flap are perforator variations, learning curve and color match. ALT flap perforators are dominantly rising from musculocutaneous perforators. ${ }^{[24,25]}$ Chasing of perforators in the muscle can take time. In these cases, adding muscle cuff is advocated for safer harvesting. [25] We believe it has a learning curve. Thus, the operative time was shorter in our latest cases. Likewise, perforator variations, color match, and skin thickness which is another problem in ALT flap, are affected by ethnic and individual characteristics. ${ }^{[26,27]}$ Subcutaneous fat thickness is lower in the Asian population where the ALT flap was popularized. In the Turkish population, flap is slightly bulky due to fascia to skin thickness. This would not be a problem in skinny patients like in our cases, but the problem can be solved by superficial elevation of the flap. ${ }^{[28]}$ 


\section{Conclusion}

The findings obtained in this study suggest that ALT flap is a versatile perforator flap that can be used safely in different anatomic locations in burn contracture.

Ethics Committee Approval: The data of patients who were operated on for the diagnosis of burn contracture and reconstructed with ALT flap were searched retrospectively. Thus, no special ethic committee approval was needed for this study.

Consent on Publication: A consent form was prepared and signed to cases number 4, 6, 7 for their permission for publishing their pre-operative and post-operative images.

Availability of Data and Material: The patient list, images and patients' data is stored and kept in Celal Bayar University Faculty of Medicine Department of Plastic Surgery achieve.

Peer-review: Internally peer-reviewed.

Authorship Contributions: Concept: Z.U.B., B.Ö.; Design: Z.U.B., B.Ö.; Supervision: N.E., L.Y.; Resource: Z.U.B., B.Ö.; Materials: Z.U.B., B.Ö.; Data: Y.K., Z.U.B.; Analysis: Y.K., Z.U.B.; Literature search: B.Ö.; Writing: B.Ö.; Critical revision: N.E., L.Y.

\section{Conflict of Interest: None declared.}

Financial Disclosure: The authors declared that this study has received no financial support.

\section{REFERENCES}

1. Song YG, Chen GZ, Song YL. The free thigh flap: A new free flap concept based on the septocutaneous artery. Br J Plast Surg 1984;37:14959. [CrossRef]

2. Luo S, Raffoul W, Luo J, Luo L, Gao J, Chen L, et al. Anterolateral thigh flap: A review of 168 cases. Microsurgery 1999;19:232-8. [CrossRef]

3. Stekelenburg CM, Marck RE, Tuinebreijer WE, de Vet HC, Ogawa R, van Zuijlen PP. A systematic review on burn scar contracture treatment: Searching for evidence. J Burn Care Res 2015;36:e153-61. [CrossRef]

4. Heidekrueger PI, Broer PN, Tanna N, Ninkovic M. Postburn head and neck reconstruction: An algorithmic approach. J Craniofac Surg 2016;27:150-5. [CrossRef]

5. Furnas DW, Fischer GW. The Z-plasty: Biomechanics and mathematics. Br J Plast Surg 1971;24:144-60. [CrossRef]

6. Hudson DA, Renshaw A. An algorithm for the release of burn contractures of the extremities. Burns 2006;32:663-8. [CrossRef]

7. Ertaş NM, Borman H. Double opposing rectangular advancement flap is an alternative technique in the treatment of wide linear postburn scar contractures. Burns 2011;37:1449-57. [CrossRef]

8. Ertaş NM, Bozdoğan N, Erbaş E, Üsçetin İ, Küçükçelebi A, Çelebioğlu $\mathrm{S}$. The use of subcutaneous pedicle rhomboid flap in the treatment of postburn scar contractures. Ann Plast Surg 2004;53:235-9. [CrossRef]

9. Gao JH, Ogawa R, Hyakusoku H, Lu F, Hu ZQ, Jiang P, et al. Reconstruction of the face and neck scar contractures using staged transfer of expanded "Super-thin flaps". Burns 2007;33:760-3. [CrossRef]

10. Feng L, Gao J, Ogawa R, Hu Z, Jiang P, Feng C. Bilateral expanded cer- vico-pectoral "super-thin flap" for entire neck reconstruction. Ann Plast Surg 2009;63:404-8. [CrossRef]

11. Verhaegen PD, Stekelenburg CM, van Trier AJ, Schade FB, van Zuijlen PP. Perforator-based interposition flaps for sustainable scar contracture release: A versatile, practical, and safe technique. Plast Reconstr Surg 2011;127:1524-32. [CrossRef]

12. Chandrasegaram MD, Harvey J. Full-thickness vs split-skin grafting in pediatric hand burns-a 10-year review of 174 cases. J Burn Care Res 2009;30:867-71. [CrossRef]

13. Iwuagwu FC, Wilson D, Bailie F. The use of skin grafts in postburn contracture release: A 10-year review. Plast Reconstr Surg 1999;103:1198204. [CrossRef]

14. Fifer TD, Pieper D, Hawtof D. Contraction rates of meshed, nonexpanded split-thickness skin grafts versus split-thickness sheet grafts. Ann Plast Surg 1993;31:162-3. [CrossRef]

15. Abramson DL, PribazJJ, Orgill DP. The use of free tissue transfer in burn reconstruction. J Burn Care Rehabil 1996;17:402-8. [CrossRef]

16. Parmaksizoğlu AF, Unal MB, Cansü E. The reconstruction of foot soft tissue defects by tangential debulking of the latissimus dorsi flap. J Reconstr Microsurg 2011;27:211-4. [CrossRef]

17. Takushima A, Harii K, Asato H. Expanded latissimus dorsi free flap for the treatment of extensive post-burn neck contracture. J Reconstr Microsurg 2002;18:373-7. [CrossRef]

18. Wei FC, Jain V, Celik N, Chen HC, Chuang DC, Lin CH. Have we found an ideal soft-tissue flap? An experience with 672 anterolateral thigh flaps. Plast Reconstr Surg 2002;109:2219-26. [CrossRef]

19. Xu DC, Zhong SZ, Kong JM, Wang GY, Liu MZ, Luo LS, et al. Applied anatomy of the anterolateral femoral flap. Plast Reconstr Surg 1988;82:305-10. [CrossRef]

20. Boca R, Kuo YR, Hsieh CH, Huang EY, Jeng SF. A reliable parameter for primary closure of the free anterolateral thigh flap donor site. Plast Reconstr Surg 2010;126:1558-62. [CrossRef]

21. Koshima I, Fukuda H, Yamamoto H, Moriguchi T, Soeda S, Ohta S. Free anterolateral thigh flaps for reconstruction of head and neck defects. Plast Reconstr Surg 1993;92:421-8; discussion 429-30. [CrossRef]

22. Acartürk TO. Aesthetic reconstruction of the postburn neck contracture with a preexpanded anterolateral thigh free flap. J Craniofac Surg 2014;25:e23-6. [CrossRef]

23. Hallock GG. The preexpanded anterolateral thigh free flap. Ann Plast Surg 2004;53:170-3. [CrossRef]

24. Yu P. Characteristics of the anterolateral thigh flap in a Western population and its application in head and neck reconstruction. Head Neck 2004;26:759-69. [CrossRef]

25. Lee YC, Chen WC, Chou TM, Shieh SJ. Anatomical variability of the anterolateral thigh flap perforators: Vascular anatomy and its clinical implications. Plast Reconstr Surg 2015;135:1097-107. [CrossRef]

26. Kimata Y, Uchiyama K, Ebihara S, Nakatsuka T, Harii K. Anatomic variations and technical problems of the anterolateral thigh flap: A report of 74 cases. Plast Reconstr Surg 1998;102:1517-23. [CrossRef]

27. Nakayama B, Hyodo I, Hasegawa Y, Fujimoto Y, Matsuura H, Yatsuya $\mathrm{H}$, et al. Role of the anterolateral thigh flap in head and neck reconstruction: Advantages of moderate skin and subcutaneous thickness. J Reconstr Microsurg 2002;18:141-6. [CrossRef]

28. Hong JP, Choi DH, Suh H, Mukarramah DA, Tashti T, Lee K, et al. A new plane of elevation: The superficial fascial plane for perforator flap elevation. J Reconstr Microsurg 2014;30:491-6. [CrossRef] 
ORİJINAL ÇALIŞMA - ÖZET

\section{Farklı anatomik bölgelerdeki yanık kontraktürlerinin serbest anterolateral uyluk flebi ile rekonstrüksiyonu \\ Dr. Zülfükar Ulaş Bali, ${ }^{1}$ Dr. Burak Özkan, ${ }^{2}$ Dr. Yavuz Keçeci, ${ }^{1}$ Dr. Nilgün Ertaş, ${ }^{2}$ Dr. Levent Yoleri ${ }^{1}$}

${ }^{1}$ Celal Bayar Üniversitesi Tıp Fakültesi, Plastik, Rekonstrüktif ve Estetik Cerrahi Anabilim Dalı, Manisa

${ }^{2}$ Başkent Üniversitesi Tıp Fakültesi, Plastik, Rekonstrüktif ve Estetik Cerrahi Anabilim Dalı, Ankara

AMAÇ: Ekstremite hareketlerinde kısıtlamaya neden olan yanık kontraktürleri rekonstrükte edilmelidir. Ciddi kontraktür olgularında genellikle serbest mikrovasküler fleplere ihtiyaç vardır. İleri derecedeki kontraktürler için ideal serbest flep, büyük deri adasına ve uzun bir pediküle sahip olmalıdır. Bu özellikleri karşılayan anterolateral uyluk flebi (ALT flep) rekonstrüktif cerrahide çeşitli endikasyonlar için yaygın olarak kullanılmaktadır. Yanık kontraktüründe ALT flep kullanımı literatürdeki yanık ve aksiller kontraktürlerde tanımlanmıştır. Bu çalışmada, farklı anatomik kontraktür bölgelerinde serbest ALT flep kullanımı sunuldu.

GEREÇ VE YÖNTEM: Yaş ortalaması 36.6 olan 14 ( 12 erkek, 2 kadın) hastaya I 5 serbest ALT flep uygulandı. Boyun, aksilla, popliteal, kübital bölge, plantar ayak ve eldeki yanık kontraktür defekti ALT flep ile rekonstrükte edildi.

BULGULAR: Tam flep kaybı ile karşılaşılmadı. Bir olguda distal flep nekrozu görüldü. Tüm hastalarda hareket açıklığında belirgin düzelme görüldü. Fizik tedavi eksikliği nedeniyle el fleksör kontraktürü olan bir hastada kontraktürde nüks görüldü.

TARTIŞMA: ALT flebi çeşitli anatomik kontraktür bölgelerinde güvenle kullanılabilir. Boyun, el ve ayakta daha iyi adaptasyon ve hacimli görünümün önlenmesi için flepin suprafasyal plandan kaldırılması tercih edilebilir.

Anahtar sözcükler: ALT flep; yanık kontraktürü; yanıklar.

Ulus Travma Acil Cerrahi Derg 2021;27(3):337-343 doi: 10.14744/tjtes.2020.89195 